\title{
Double-blind Cross-over Trial Comparing Intranasal Beclomethasone Dipropionate and Placebo in Perennial Rhinitis
}

\author{
G. J. GIBSON， D. J. MABERLY， S. LAL， M. M. ALI， A. G. BUTLER
}

British Medical fournal, 1974, 4, 503-504

\begin{abstract}
Summary
Twenty-five patients with perennial rhinitis completed a double-blind cross-over trial of intranasal beclomethasone dipropionate $200 \mu \mathrm{g}$ daily and placebo. Of these patients 19 preferred the active drug and two preferred placebo. There were significant reductions in symptom scores for nasal obstruction and rhinorrhoea and in the use of decongestant nasal drops when using the active drug. No changes in morning plasma cortisol levels occurred during the threeweek treatment period.
\end{abstract}

\section{Introduction}

The treatment of perennial rhinitis is often unsatisfactory Of the conventional drugs antihistamines may cause unacceptable somnolence and decongestant drops of sympathomimetic amines often produce a rebound exacerbation of symptoms when discontinued. Intranasal sodium cromoglycate, however, is helpful in many patients (Sunderman and Crawford, 1973) and systemic steroid therapy is effective, but its use for long periods in patients whose symptoms are inconvenient rather than life threatening is rarely justified. The most commonly used intranasal steroid, dexamethasone phosphate, is effective in rhinitis (Norman et al., 1966) but causes suppression of adrenal function in the doses recommended (Norman et al., 1967; Michels et al., 1967). Betamethasone-17-valerate, however, is active in lower doses and there is little evidence of adrenal suppression (Czarny and Brostoff, 1968; Brostoff and Czarny, 1969).

Inhaled beclomethasone dipropionate (Becotide) is beneficial in the treatment of asthma in doses which do not affect adrenal function (Lal et al., 1972; Buisseret, 1973; Gaddie et al., 1973; Maberly et al., 1973) and is effective in patients with hay fever in an intranasal dose of $400 \mu \mathrm{g} /$ day without producing adrenal suppression (Mygind, 1973).

This study was designed to study the effectiveness of intranasal beclomethasone dipropionate in a dose of only 200 $\mu \mathrm{g} /$ day in a group of patients with perennial rhinitis.

\section{Patients and Methods}

The patients were studied at the General Hospital, Bury, and Hammersmith Hospital, London. All had troublesome

\footnotetext{
Department of Medicine, Royal Postgraduate Medical School, London W.12

G. J. GIBSON, M.R.C.P., Senior Registrar

D. J. MABERLY, M.R.C.P., M.R.A.C.P., Research Fellow (Present address: Consultant Physician, Airedale General Hospital, Keighley, Yorkshire)

The General Hospital, Bury, Lancashire

S. LAL, F.R.C.P., Consultant Physician

M. M. ALI, M.B., Clinical Assistant

Allen and Hanburys Research Limited, Ware, Hertfordshire A. G. BUTLER, B.sc., Senior Clinical Trials Officer
}

symptoms of nasal obstruction, irritation, or rhinorrhoea which were present throughout the year. On the basis of history and immediate skin sensitivity to prick testing with the common allergens they were classed as having "extrinsic" or "intrinsic" rhinitis. The patients were allocated at random in a double-blind fashion to two groups, one of which initially received placebo and the other active drug. After three weeks the treatments were crossed over for a further three weeks. The dose of active drug used was one puff of $50 \mu \mathrm{g}$ in each nostril twice daily. An identical procedure was used with the placebo which contained the inert carriers of the drug (freons). The code was not broken until the end of the six-week trial. The patients were allowed symptomatic use of antihistamine tablets (chlorpheniramine maleate $4 \mathrm{mg}$ ) and of a nasal decongestant $(0.5 \%$ ephedrine nose drops) and were asked to keep a diary card on which they recorded daily the number of times each treatment was used. Therapy for asthma (including oral steroids, inhaled beclomethasone dipropionate, or sodium cromoglycate) was continued unchanged. The patients were also asked to note any side effects and to grade and record on the diary card each day the following nasal symptoms_c"sneezing and itching," "running nose," and "blockage of the nose"- - on an arbitrary scale from 0 to $3(0=$ nil, $1=$ mild, $2=$ moderate, $3=$ severe). At the end of the trial each patient was asked to express a preference for one or other of the two inhalers he had used.

To avoid a "carry-over" effect statistical treatment of the symptom scores (by Wilcoxon's test) was limited to the final two weeks of each three-week period.

In most patients the plasma cortisol level was measured between 9 a.m. and 10 a.m. before the trial and after each of the two treatment periods. Cortisol was assayed by the method of Mattingly (1962).

\section{Results}

Of 30 patients entered in the trial one discontinued because of an attack of asthma, three defaulted, and one was excluded because of an alteration in prednisone dosage. Of the 25 who completed the trial 19 expressed a preference for beclomethasone dipropionate, two for placebo, and four for neither. This difference was highly significant in favour of the active drug $(P<0.001)$. Characteristics of these groups are shown in table $I$, and there were no significant differences between the patients who preferred beclomethasone dipropionate and those who did not. The mean scores for each symptom and use of antihistamine tablets and nasal drops during the final two weeks of each period are shown in table II for all the 25 patients. Rhinorrhoea and nasal obstruction were significantly improved but "sneezing and itching" were not. The use of antihistamine tablets was low in both groups with no significant difference between them, but the use of nasal drops was significantly less during the active-treatment period. The order of treatment did not significantly affect the difference between beclomethasone dipropionate and placebo.

The mean total daily symptom scores-on a scale from 0 to 9-are shown in the diagram for the two three-week 
TABLE I-Clinical Features of Patients according to preferred Treatment

\begin{tabular}{|c|c|c|c|c|c|c|c|c|}
\hline \multirow{2}{*}{ Preferred Treatment } & \multirow{2}{*}{$\begin{array}{c}\text { No. of } \\
\text { Patients }\end{array}$} & \multirow{2}{*}{$\begin{array}{c}\text { Mean (Range) } \\
\text { Age in Years }\end{array}$} & \multirow{2}{*}{$\begin{array}{l}\text { No. with } \\
\text { Asthma }\end{array}$} & \multicolumn{3}{|c|}{ No. on Treatment with: } & \multirow{2}{*}{$\begin{array}{l}\text { No. with } \\
\text { Extrinsic } \\
\text { Rhinitis }\end{array}$} & \multirow{2}{*}{$\begin{array}{l}\text { No. with } \\
\text { Intrins ic } \\
\text { Rhinitis }\end{array}$} \\
\hline & & & & Prednisone & $\begin{array}{l}\text { Sodium } \\
\text { Cromoglycate }\end{array}$ & $\begin{array}{c}\text { Inhaled } \\
\text { Beclomethasone } \\
\text { Diproprionate }\end{array}$ & & \\
\hline $\begin{array}{l}\text { Beclomethasone dipropionate } \\
\text { Placebo } . . \\
\text { Neither }\end{array}$ & $\begin{array}{r}19 \\
2 \\
4\end{array}$ & $\begin{array}{l}37(22-54) \\
36(30-42) \\
37(14-50)\end{array}$ & $\begin{array}{r}16 \\
1 \\
3\end{array}$ & $\begin{array}{l}0 \\
0 \\
1\end{array}$ & $\begin{array}{l}2 \\
0 \\
0\end{array}$ & $\begin{array}{l}7 \\
1 \\
2\end{array}$ & $\begin{array}{r}13 \\
0 \\
3\end{array}$ & $\begin{array}{l}6 \\
2 \\
1\end{array}$ \\
\hline
\end{tabular}

TABLE II-Mean Scores for Symptoms and Use of Nasal Drops and Antihistamine Tablets during Last Two Weeks of each Treatment Period

\begin{tabular}{|c|c|c|c|c|}
\hline & & & Score & $\mathbf{P}$ \\
\hline \multicolumn{5}{|c|}{ Running Nose } \\
\hline Beclomethasone & .. & . & $\begin{array}{r}4.3 \\
8.6\end{array}$ & \multirow[t]{2}{*}{$<0.005$} \\
\hline Placebo $\quad .$. & $\cdots$ & $\cdots$ & $\begin{array}{l}\text { Blocked Nose } \\
8.6\end{array}$ & \\
\hline $\begin{array}{l}\text { Beclomethasone } \\
\text { Placebo }\end{array}$ & .. & .. & \begin{tabular}{l|r}
$\ldots$ & 12.3 \\
$\therefore$ & 18.7
\end{tabular} & \multirow[t]{2}{*}{$<0.005$} \\
\hline Placebo $\quad$. & . & - & Sneezing and Itching & \\
\hline $\begin{array}{l}\text { Beclomethasone } \\
\text { Placebo }\end{array}$ & .. & . & \begin{tabular}{l|l}
$\cdots$ & $6 \cdot 7$ \\
\end{tabular} & \multirow[t]{2}{*}{ N.S. } \\
\hline Placebo $\quad \cdots$ & $\cdots$ & $\cdots$ & Use of Nasal Drops & \\
\hline Beclomethasone & . & . & \begin{tabular}{l|l}
.. & 3.9 \\
\end{tabular} & \multirow[t]{2}{*}{$<0.05$} \\
\hline Placebo $\quad .$. & $\cdots$ & $\cdots$ & $\ddot{U}_{\text {se of Antihistamines }}$ & \\
\hline Beclomethasone & .. & . & . 10 & \\
\hline Placebo $\quad .$. & $\cdots$ & $\cdots$ & 0.1 & \\
\hline
\end{tabular}

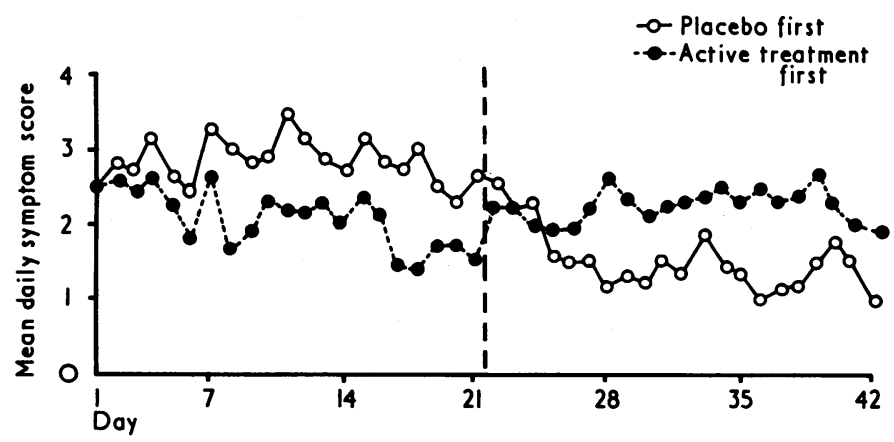

Mean daily total symptom scores for two groups of patients during two three-week periods on beclomethasone dipropionate and placebo. Cross-over between treatments is indicated by broken line.

periods, and the overall improvement on beclomethasone dipropionate can be seen. The cross-over point on the graph occurred on the fourth day of the second period.

The mean pretreatment plasma cortisol level was 16.8 $\mu \mathrm{g} / \mathrm{ml}$ and the mean levels after three weeks' treatment with active drug and placebo were, respectively, $17.5 \mu \mathrm{g} /$ $100 \mathrm{ml}$ and $17.4 \mu \mathrm{g} / 100 \mathrm{ml}$ with no evdence of suppression of adrenal function.

The only side effects recorded were a stinging sensation in the nose and sneezing, each noted by one patient and in each case when using both the active and placebo inhalers.

\section{Discussion}

Though their symptoms were not completely relieved most patients with perennial rhinitis improved on treatment with beclomethasone diproprionate $200 \mu \mathrm{g} /$ day. The beneficial effects seemed to apply to both the extrinsic and intrinsic groups though the number of patients in the intrinsic group was small. The results contrast with those of treatment with betamethasone-17-valerate (Czarny and Brostoff, 1968), which produced improvement only in patients with evidence of specific allergies. The only other published study on intranasal beclomethasone dipropionate (Mygind, 1973) showed clear evidence of improvement in 25 out of 29 patients with seasonal extrinsic rhinitis (pollen hay fever) receiving $400 \mu \mathrm{g} /$ day. The percentage of patients responding in our series was almost as high with only half the dose though the improvement was less dramatic. The reduction in need for decongestant drops is further evidence of benefit and the low usage of antihistamine tablets merely reflects the rather poor relief the patients obtained from them.

Our results also showed that beclomethasone dipropionate was more effective in relieving nasal obstruction and rhinorrhoea than in relieving sneezing and itching. Possibly the beneficial effect of the drug is counteracted by an irritant effect of the vehicle as two patients experienced irritation and sneezing when using both the active drug and placebo. Similar effects were noted by 16 of the 24 patients treated by Mygind (1973).

Though the plasma cortisol levels showed no evidence of adrenal suppression measurement of only the resting value is a relatively insensitive test of adrenal function. There is, however, now much evidence that from 400 to $800 \mu \mathrm{g}$ beclomethasone dipropionate can be given daily by conventional aerosol without any impairment of adrenal function (Buisseret, 1973; Harris et al., 1973), and a daily dose of $400 \mu \mathrm{g}$ by the intranasal route for two weeks has no significant effect on the excretion of 17-ketogenic steroids (Mygind, 1973). Moreover, while daily doses of more than $2 \mathrm{mg}$ by inhalation can cause suppression of morning plasma contisol levels (Harris et al., 1973) up to $8 \mathrm{mg}$ daily by the nasal route has no such effect (Harris et al., 1974).

We conclude that intranasal beclomethasone dipropionate in a dose as low as $200 \mu \mathrm{g}$ daily is a useful addition to the therapy of perennial rhinitis.

We thank Mr. A. J. Davey for statistical help. Allen and Hanburys Research Limited, Ware, Hertfordshire, supplied the materials used.

\section{References}

Brostoff, J., and Czarny, D. (1969). Journal of Allergy, 44, 77.

Buisseret, P. D. (1973). Acta Allergologica, 28, 126.

Czarny, D., and Brostoff, J. (1968). Lancet, 2, 188.

Gaddie, J., et al. (1973). Lancet, 1, 691.

Harris, D. M., et al. (1973). Clinical Allergy, 3, 243.

Harris, D. M., et al. (1974). Clinical Allergy. In press.

Lal, S. et al. (1972). British Medical fournal, 3, 314 .

Maberly; D. J., Gibson, G. J., and Butler, A. G. (1973). British Medical fournal, 1,778.

Mattingly, D. (1962). Fournal of Clinical Pathology, 15, 374.

Michels, M. I., Smith, R. E., and Heimlich, E. M. (1967). Annals of Allergy, 25, 569 .

Mygind, N. (1973). British Medical fournal, 4, 464.

Norman, P. S., et al. (1967). ₹ournal of Allergy, 40, 1, 57.

Norman, P. S., et al. (1966). Ұournal of Allergy, 38, 93.

Sunderman, J., and Crawford, W. A. (1973). Medical fournal of Australia, 1, 1189. 